\title{
Education And Training of Bengawan Solo Water Cleaning Using Filtration Method in Karanggeneng Village, Karanggeneng District, Lamongan Regency
}

\author{
Mimatun Nasihah*, Nur Lathifah Syakbanah, Gading Wilda Aniriani, Andini Dwi \\ Magfiroh
}

\author{
Environmental Health Study Program, Faculty of Health Sciences, Lamongan Islamic University \\ ${ }^{*}$ Corresponding author email: mima@unisla.ac.id
}

\begin{abstract}
The northern part of Lamongan Regency is an area that is geologically and geographically vulnerable to freshwater. The condition of the existing water sources is not suitable for use as a source of clean water, because the water is brackish and green in color. The eutrophication process occurs due to excessive use of fertilizers for pond business, so that the nitrogen and phosphate content is high. The community in Karanggeneng village uses water from the Bengawan Solo River for daily use. The water condition of Bengawan Solo in the rainy season is dark brown in color because it contains a lot of soil, while in the dry season it is green because it contains a lot of pesticide or fertilizer residues discarded by farmers. From the problems above, it is necessary to socialize the water purification of Bengawan Solo by using the filtration method. Socialization activities are carried out directly to the Karanggeneng village community. This activity is carried out in two stages, the first is the preparation of tools and materials, the second stage is socialization to the community. In the first stage, chemical and physical water quality parameters were tested. In the second stage, the community was very enthusiastic about the implementation of this activity. The use of filtration methods is easy and inexpensive to be applied on a household scale. Suggestions, it is necessary to disseminate information to the wider community so that all people can access clean water for their daily needs. the second stage is socialization to the community. In the first stage, chemical and physical water quality parameters were tested. In the second stage, the community was very enthusiastic about the implementation of this activity. The use of filtration methods is easy and inexpensive to be applied on a household scale. Suggestions, it is necessary to disseminate information to the wider community so that all people can access clean water for their daily needs. the second stage is socialization to the community. In the first stage, chemical and physical water quality parameters were tested. In the second stage, the community was very enthusiastic about the implementation of this activity. The use of filtration methods is easy and inexpensive to be applied on a household scale. Suggestions, it is necessary to disseminate information to the wider community so that all people can access clean water for their daily needs.
\end{abstract}

Keywords: Solo River, Water Purification, Filtration Method

\section{INTRODUCTION}

The northern part of Lamongan Regency is an area that is geologically and geographically vulnerable to freshwater. Part of the area is by the sea where aquaculture is the mainstay of the people's business. The condition of the existing water sources is not suitable for use as a source of clean water, because the water is brackish and green in color. The eutrophication process occurs due to excessive use of fertilizers for pond business, so that the nitrogen and phosphate content is high. The process of industrialization, deforestation, agricultural mechanization, and the unorganized urban sewage treatment system, especially along rivers, have made surface water conditions, both quality and quantity adequate to meet human needs, increasingly scarce. The condition of running water in water bodies does not meet the quality requirements as raw material for drinking water.

The community in Karanggeneng village uses water from the Bengawan Solo River for daily use. In Karanggeneng village itself there is a water installation called kumpo, water house, 
or water filtration from Bengawan Solo to people's houses. The purification belongs to the Karanggeneng village government. And the common problem found in Karanggeneng village is about clean water. The clean water used by the people of Karanggeneng village can be categorized as poor, because it can be seen that the color of the water used is brown, the cause of the brown water is the mixing of mud and water in the Bengawan Solo river, and the filtration equipment in the village which is destined for the village stream is not functioning. well.

Filtration is the separation of colloids or solid particles from a fluid by using a filtering medium or filter. Water containing a solid or colloid is passed through a filter medium with a pore size smaller than the size of the solid. Filtration is a process of separating solids from fluids (gas or liquids) which carry them using a porous medium or other porous material to remove as much as possible suspended fine solids and colloids. In addition to reducing the content of solids, filtration can also reduce bacteria, remove color, taste, odor of iron, and manganese.

This socialization is used or carried out by lecturers and students of the faculty of health sciences for the community in the village of Karanggeneng is to provide knowledge to the village community to find out how to clean water and how to use simple filtration that can be done at home, using simple filtration, and easy materials. obtained and found around the village of Karanggeneng.

Although most of the people in Karanggeneng village already have knowledge, but there are still people who are lagging behind in terms of education and at the same time a low economy. So that knowledge they do not understand health and water treatment technology.

The purpose of this water purification socialization counseling is to provide knowledge and socializing the importance of clean water for health, as well as providing knowledge how to treat clean water in a simple way using multilevel filtration

\section{MATERIALS AND METHODS}

This Community Service activity will be held on Sunday, July 25, 2021. At 15.00 WIB until it is finished in Karanggeneng Village, Karanggeneng District, Lamongan Regency.

\section{Map Access to Location}

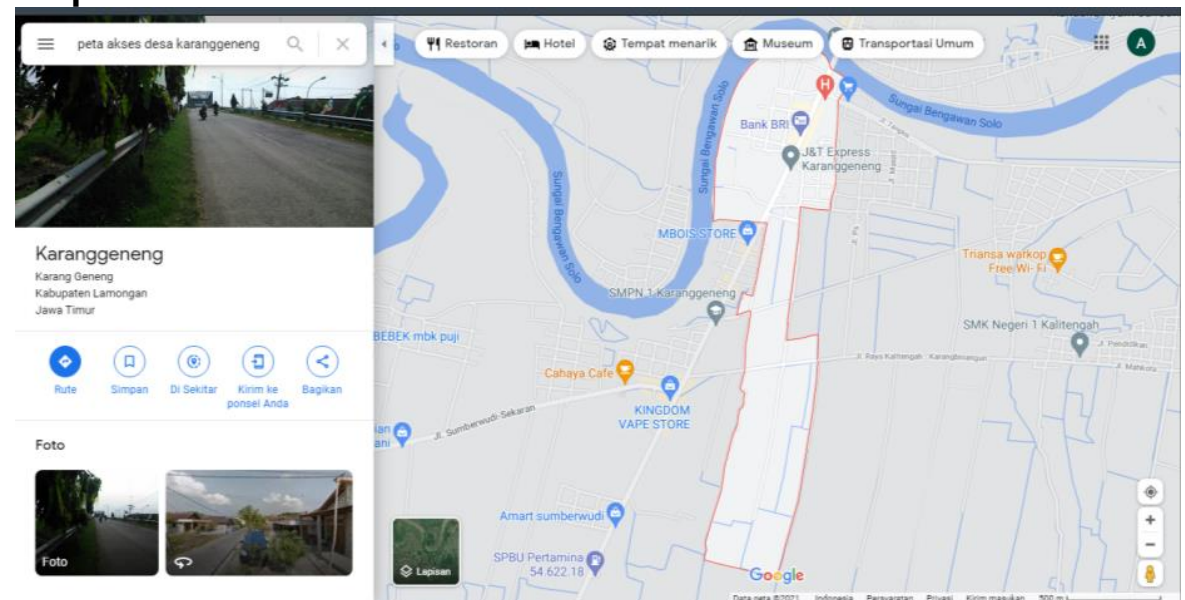

The equipment used includes:

Tong / Container. Consists of a simple plastic or jar with a volume of 70-80 liters. The jar is equipped with a faucet at the bottom of the jar to drain water that has passed through a multilevel water purification arrangement. Used to make it easier to drain clear water. In making these filtration jars, glue, solder, faucet, and a little bit of paralon are needed.

Charcoal.Charcoal here is placed at the very top in the filtration process. The function of charcoal in water purification is as activated carbon in filtering water to purify the water. This is because the charcoal contains activated carbon which can work by absorption or absorption. That is, when there is a material or object that passes through the activated carbon, the material contained in it will be absorbed. So that it is not surprising that this material (charcoal with its 
activated carbon content) is able to take some of the bad ingredients from polluted water, including in the process of filtering water to purify it and remove odors from the water.

Gravel.The gravel is placed in the second layer after the charcoal. The function of the gravel in this multilevel clean water purification isto filter out large debris such as moss, leaves, or animals. The pebbles also function asas a filter material and helps oxygen aeration.

Sand. Then next is sand, sand in water purification is used to hold the silt that is carried by the Bengawan Solo river water.

ljuk. The next layer, which is the fourth layer, has palm fiber which functions to filter out particles that have escaped in the previous layer so that at the last layer the water is clean and can be used.

Dacron/sponge. The last layer is occupied by sponges and dacron, in water purification it is used to absorb water deposits that make the water color cloudy.

How Filtration Technology Works for Water Filtration

a. Water purification jars are provided, with all the equipment that has been made including water faucets etc

b. Clean the filter media so that no dirt is dissolved during the water application process.

c. Then for the filter media, starting from the most intense, namely dacron/sponge, palm fiber, sand, gravel and charcoal.

d. Arrange the media neatly so that there are no layers or spaces that make the particles in the water escape.

e. Enter the raw water (river) that has been provided into the filtration jar

f. Deposit for a few minutes so that the water particles can be filtered by the filtration media in the jar.

g. After that, open the faucet with minimal speed so that the water produced is clean and clear.

\section{RESULTS}

Community Service activities began with preparing tools and materials in the Laboratory of the Faculty of Health Sciences, conducting water purification trials, then testing water quality before and after using filtration technology. The tests carried out were physical parameters including color, taste and odor and chemical parameters, namely the $\mathrm{pH}$ test.

The test results show that there is a significant difference between before and after being inserted into the filtration apparatus. The results of this stratified water purification practice test obtained that water that had passed the water purification media mentioned above, obtained physically clear and clean water. Not cloudy before filtration. Prior to filtration, our group did a $\mathrm{pH}$ test to find out what the $\mathrm{pH}$ level of the raw water (river) was. It turns out that the raw water / river has a $\mathrm{pH}$ of 5 which means it is included in the alkaline group, but after cleaning the water the $\mathrm{pH}$ is 7 which means that the level is included in the normal category. For others, such as the color of the water physically, the color of the water changes, from initially cloudy to clean and clear. And next for the smell at the time before and after filtration.

Testing of filter equipment is equipped with socialization and training of tool making to the people of Karanggeneng village. The socialization of the filter test was carried out by inviting people whose groundwater quality represented the test sample for socialization at Rt 03 Rw 01 Karanggeneng Village on Sunday, July 25 2021. how to make a filter tool and where to get filter material. The public also received information about the test results of the filter equipment and how to maintain the filter equipment.This activity is limited to a few residents because it is still during the PPKM Covid pandemic. The schedule for the socialization activity is actually July 7 , 2021, which will be held at the village hall, targeting PKK women, but due to restrictions on activities involving many people, this activity brings several residents in Karanggeneng village. 


\section{DISCUSSION}

The socialization activity of Bengawan Solo water purification using the filtration method. In the implementation of socialization activities and training on making filter tools, students brought material using media props in the form of prototype filters. At the end of the activity, an interactive discussion was held so that the community could exchange ideas with students about clean water problems in Karanggeneng village and the possible solutions offered. In this session, the community also explores information about the design, manufacturing techniques, materials used and the estimated cost of making filters. It is hoped that with this activity there will be more efforts and willingness from the community to improve the quality of healthy life by paying attention to aspects of the availability and use of clean water.

\section{CONCLUSIONS AND SUGGESTIONS}

One of the sanitation problems faced by the people of Karanggeneng village is that the clean water used daily is still inadequate, marked by the cloudy nature of the water. This can be overcome with a filter that is able to make the water clearer. The filter made is a simple filter as an example to be published to the Karanggeneng village community with the aim that the Karanggeneng Village community is able to independently solve the problem of clean water that is cloudy.

To maximize the performance of the filter, it is necessary to carry out a complete laboratory test and wash the filtration media, because the laboratory test is very helpful in monitoring the materials and quality of the water used. This is very helpful in making decisions for the next stage of creating a simple filter.

\section{ANKNOWLEDMENT}

We would like to express our gratitude to those who have supported the implementation of this community service activity. First of all, we would like to thank the Institute for Research, Development and Community Service (Litbang Pemas) of Lamongan Islamic University for providing opportunities and funding for this community service activity. Further thanks to the Head of Karanggeneng Village and Karanggeneng Village Residents who have given permission to carry out this community service activity.

\section{REFERENCES}

Sugito, S and Asmoro, P. 2012. "Application of Filtering Technology towards Clean Water in Sumberwudi Karanggeneng, Lamongan Regency" Journal of Time: Journal of Engineering Unipa ISSN 2715-4947. Vol 10 No. 01.

Duta, S. 2021. "The function of charcoal in water purification is that it can remove odors!" accessed fromhttps://vagusnet.com/function-charcoal-pada-purification-water/ on March 10,2021

Kristianto, et al. 2016. "Application of Simple Water Filtration Technology in Cukanggenteng Village" Journal of Udayana Serving. Volume 15 Number 03. September 2016

Margono, 2010. Pocket book of field workers Kridanirmala Poltekes, Ministry of Health Surabaya

Asmadi, Khayan. Heru Subarsi Kasjono, 2011. "Drinking Water Treatment Technology" Goysen publicis Yogyakarta,. 


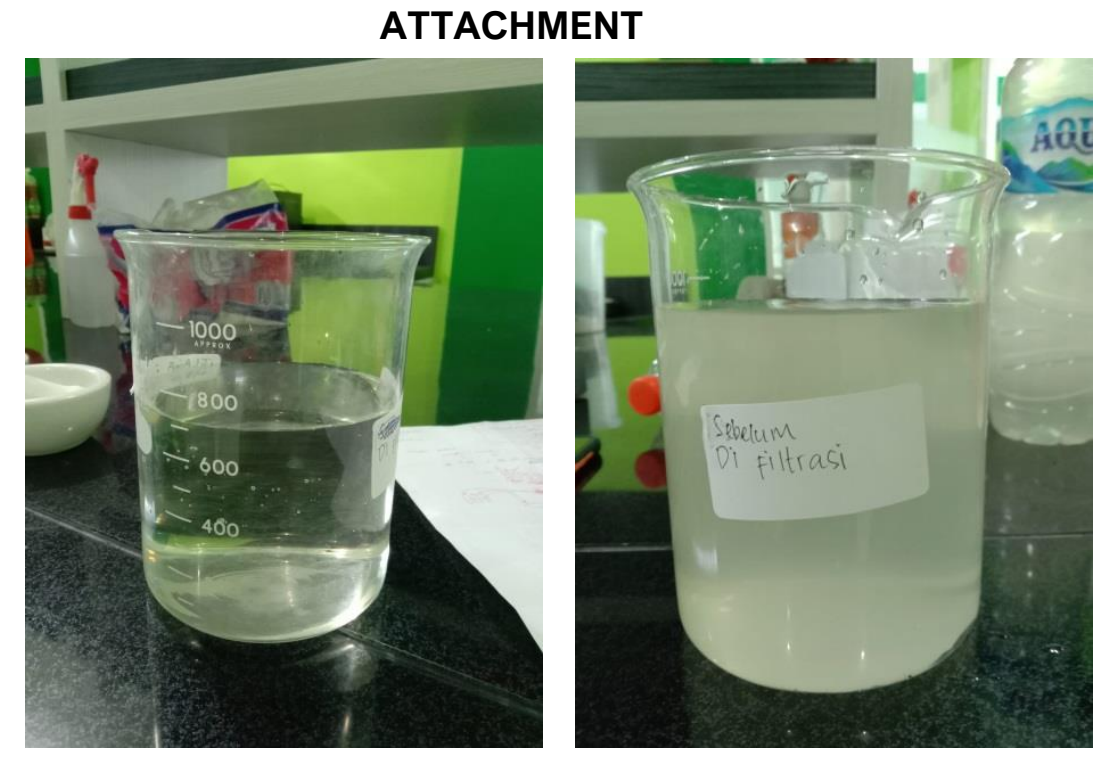

Figure 1 Before and after filtration
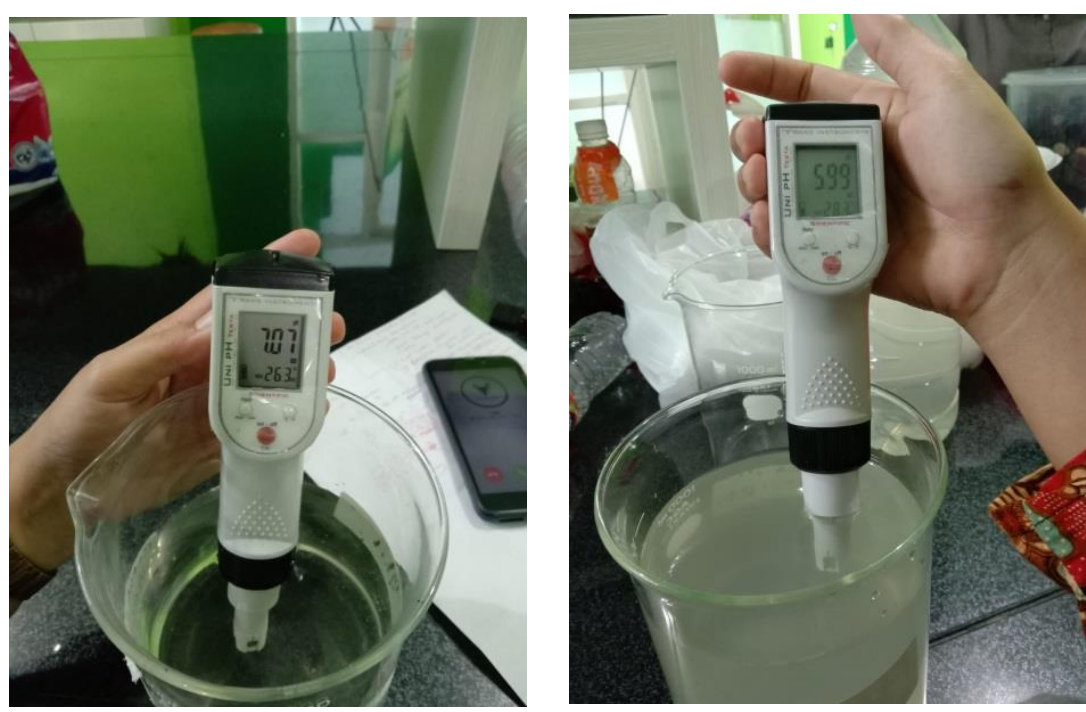

Figure 2 testing the $\mathrm{pH}$ of water before and after
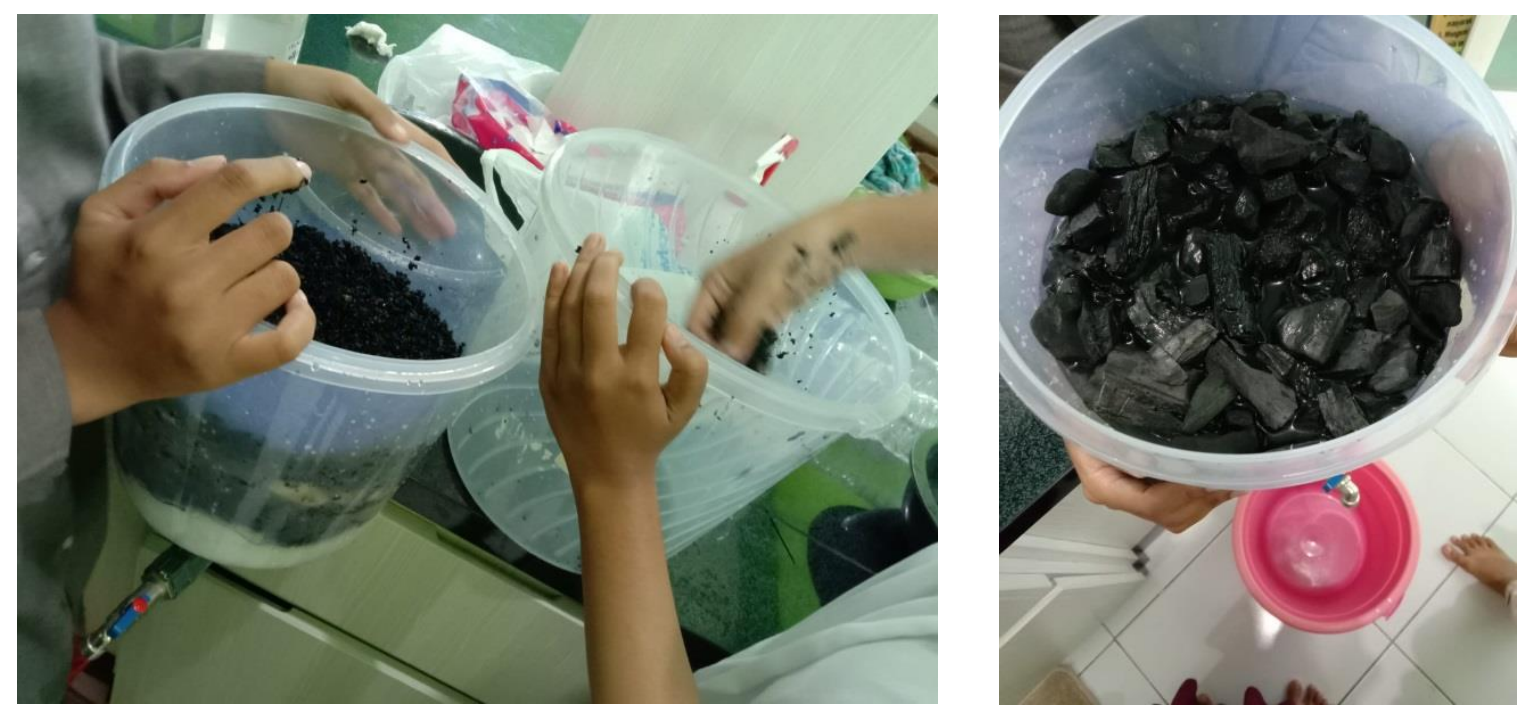

Figure 3 The process of preparing the filtration media 

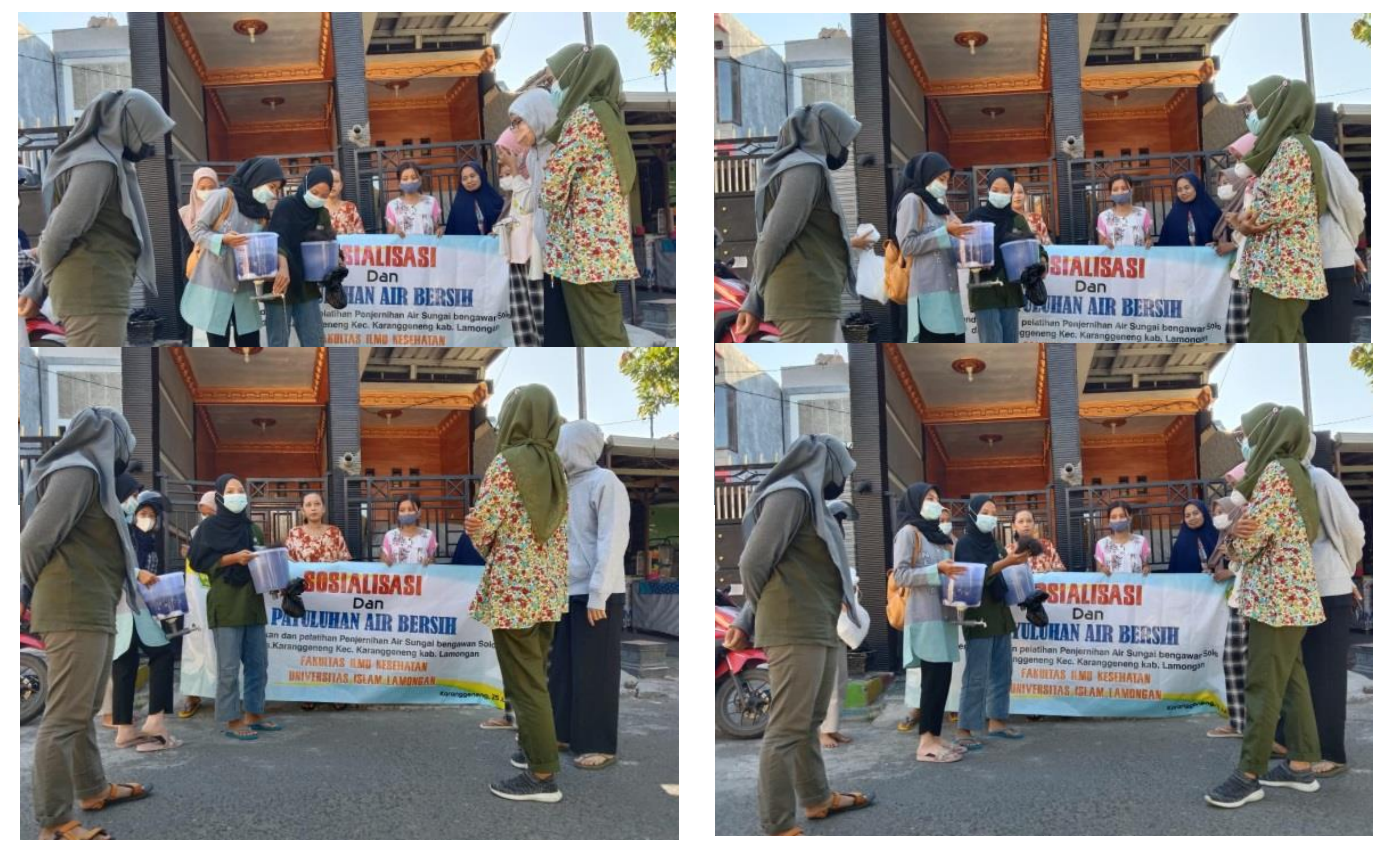

Figure 4. Socialization of Water Purification Using the Filtration Method in the Karanggeneng Village Community, Karanggeneng Lamongan District 